AKUNTABILITAS

Vol. VII No. 3, Desember 2014

P-ISSN: $1979-858 \mathrm{X}$

Halaman 196 - 210

\title{
PERBANDINGAN KINERJA KEUANGAN ANTARA BANK SYARIAH DENGAN BANK KONVENSIONAL SETELAH DIKELUARKAN \\ UNDANG-UNDANG NOMOR 21 TAHUN 2008 TENTANG PERBANKAN SYARIAH
}

\author{
Yessi Fitri \\ UIN Syarif Hidayatullah Jakarta
}

\begin{abstract}
The purpose of this study is to compare the financial performance of Islamic banks against conventional banks after enactment of Indonesia's Islamic Banking Act No 21/2008. The data was based on selected financial statements of Islamic banks and conventional banks in Indonesia from year 2009 to 2011 . Financial performance measures were expressed in term of various financial ratios in which were categorized into profitability, liquidity, risk, solvency and efficiency. To test the hipotheses, Mann-Whitney was employed to compare financial performance. In general, the study found no major difference in financial performance between Islamic banks and conventional banks except in term of its ROA and EM. This indicated that conventional banks are generally more profitable as compared to conventional banks but failure risk of islamic banks are smaller than conventional banks.
\end{abstract}

Keywords: Islamic Banking, Profitabilitas, Liquidity, Risk, Solvency and Efficiency.

ABSTRAK: Tujuan dari penelitian ini adalah untuk membandingkan kinerja keuangan bank syariah terhadap bank konvensional setelah berlakunya Undang-undang No.21 tahun 2008 tentang perbankan syariah di Indonesia. Data ini didasarkan pada laporan keuangan yang dipilih dari bank syariah dan bank konvensional di Indonesia dari tahun 2009 hingga 2011. Ukuran kinerja keuangan yang disajikan dalam berbagai rasio keuangan yang dikategorikan ke dalam profitabilitas, likuiditas, risiko, solvabilitas dan efisiensi. Untuk menguji hipotesis digunakan Mann-Whitney untuk membandingkan kinerja keuangan. Secara umum, penelitian ini tidak menemukan perbedaan besar dalam kinerja keuangan antara bank syariah dan bank konvensional kecuali dalam hal ROA dan EM. Hal ini menunjukkan bahwa bank-bank konvensional umumnya lebih menguntungkan dibandingkan dengan bank konvensional namun risiko kegagalan bank syariah lebih kecil dari bank konvensional.

Kata kunci: Perbankan Islam, Profitabilitas, Likuiditas, Risiko, Solvabilitas dan Efisiensi.

\footnotetext{
1 *Draft pertama: 10 September 2014 ; Revisi: 16 Oktober 2014 ; Diterima: 15 November 2014 Penulis dapat dikontak melalui: yessi.fitri@uinjkt.ac.id
} 


\section{PENDAHULUAN}

Kebutuhan terhadap institusi keuangan Islam timbul untuk memfasilitasi komunitas muslim. Masyarakat pindah ke sistem keuangan Islam karena kharakteristik sebagai berikut: (1) inovasi dan fairness dalam transaksi (2) pembagian risiko dan return yang sama antara stakeholders (3) standar etika yang diikuti oleh sistem keuangan Islam yaitu tidak mengeksploitasi dan untuk kemakmuran sosial ((Laghari et. al., 2011). Pertumbuhan usaha perbankan syariah di Indonesia terbilang cepat dan menjanjikan, dalam arti bahwa bisnis ini sangat jelas memiliki prospek yang cerah. Dibanding Malaysia yang telah sepuluh tahun lebih dahulu mengembangkan dan mengimplementasikan perbankan syariah, perkembangan di Indonesia boleh dibilang lebih menjanjikan. Paling tidak secara nominal hingga tahun 2004, tingkat pertumbuhan perbankan syariah mencapai angka fantastis $60 \%$, sementara untuk tahun 2005 hingga tahun 2006 sedikit melambat dan hanya mencapai 30\%. Meskipun, jika dilihat dari pangsa pasar yang ada perbankan syariah baru memiliki pangsa $2 \%$, sementara di Malaysia mencapai $15 \%$, namun jika dilihat secara nominal, pertumbuhannya telah mencapai angka yang sama. Kelebihan perbankan syariah dibanding perbankan konvensional adalah pada nilai-nilai yang dianut. Perbankan syariah karena didasarkan pada nilai-nilai Islam, maka jelas lebih islami. Selain itu, perbankan syariah juga mematok nilai-nilai governance dan transparansi sebagai ruh dalam kegiatan usaha yang dijalankan (Zuhdi, 2007). Haniffa dan Hudaib (2007) juga menyatakan bahwa bank syariah memiliki identitas etis karena tujuan sosial bank syariah sama pentingnya dengan tujuan keuangan karena fakta bahwa bank syariah berdasarkan syariah Islam yang memiliki tujuan utamanya yaitu perbaikan masyarakat.

Senada dengan yang disampaikan oleh Bank Indonesia (BI) bahwa BI optimis pangsa pasar perbankan syariah terhadap industri perbankan dari segi aset bisa meningkat menjadi 10 persen dalam lima tahun mendatang. Saat ini, perbankan syariah baru memegang 4 persen dari pangsa pasar. Hal tersebut bisa tercapai lantaran BI melihat tren pertumbuhan perbankan syariah dalam lima tahun terakhir. Deputi Gubernur BI Halim Alamsyah mengungkapkan aset perbankan syariah rata-rata tumbuh 40,5 persen selama lima tahun terakhir. Pertumbuhan ini mencakup bank syariah, unit usaha syariah, maupun BPR syariah. Angka tersebut dua kali lebih cepat daripada pertumbuhan perbankan konvensional (Djumena, 2012).

Kalau pertumbuhannya bisa berlanjut seperti sekarang, bukan mustahil dalam lima tahun mendatang pangsa pasar syariah bisa mendekati 10 persen. Kalau ditambah lima tahun lagi bisa 15 persen," ungkap Halim saat membuka Musyawarah Nasional Asosiasi Bank Syariah Indonesia (Asbisindo), Rabu (21/3/2012). Melihat data BI per Januari 2012, untuk aset bank umum syariah saja terjadi peningkatan nilai aset sebesar 47,43 persen menjadi Rp115,296 triliun dibandingkan Januari 2011 sebesar Rp78,203 triliun. Untuk mencapai target pangsa pasar mendekati to persen dalam lima tahun mendatang, menurut Halim ada beberapa tantangan yang harus dihadapi industri perbankan syariah. Pertama, peningkatan kuantitas dan kualitas sumber daya manusia. Kedua, peningkatan inovasi produk dan layanan yang kompetitif. Ketiga, keberlangsungan edukasi dan sosialisasi kepada masyarakat (Djumena, 2012).

Undang-Undang No.21 Tahun 2008 tentang Perbankan Syariah yang telah dikeluarkan dan terbit tanggal 16 Juli 2008 menjadikan industri perbankan syariah nasional semakin memiliki landasan hukum yanmg memadai. Karena memiliki landasan hukum yang memadai maka akan mendorong pertumbuhan industri yang semakin cepat. Bank Syariah memiliki ROA yang lebih tinggi karena mereka mampu meminimalkan biaya overhead dibanding bank konvensional (Rosly and Bakar, 2003).

Dengan dikeluarkan Undang-Undang No.21 Tahun 2008 tentang Perbankan Syariah maka diharapkan terjadi peningkatan kinerja bank syariah baik kinerja keuangan maupun non keuangan. Peneliti ingin mengetahui perbandingan kinerja keuangan bank syariah 
dengan bank konvensional. Penelitian ini mengacu pada penelitian yang dilakukan oleh Hanif et. al., (2011), penelitian Ika dan Abdullah (2011) dan Bilal et. al., (2011). Dalam hal ini terdapat gap penelitian dimana Hanif et. al., (2011) menyatakan dalam hal profitabilitas dan likuiditas bank konvensional kinerjanya lebih baik, sedangkan dalam manajemen risiko kredit dan pemeliharaan solvabilitas perbankan syariah lebih baik, sedangkan Ika dan Abdullah (2011) secara umum tidak menemukan perbedaan besar dalam kinerja keuangan antara bank syariah dengan bank konvensional, kecuali dalam hal likuiditas. Penelitian mereka menunjukkan bahwa bank syariah lebih likuid daripada bank konvensional. Penelitian Bilal et. al., (2011) menyimpulkan bahwa bank-bank Islam lebih efisien daripada bank-bank komersial kecil di Pakistan. Karena terdapat gap penelitian maka peneliti ingin meneliti kembali perbandingan kinerja keuangan bank syariah dengan bank konvensional setelah dikeluarkannya undang-undang nomor 21 tahun 2008 tentang perbankan syariah. Tujuan yang hendak dicapai dalam kegiatan penelitian antara lain: menganalisa kinerja keuangan perbankan syariah jika dibandingkan dengan perbankan konvensional untuk masing -masing rasio keuangan setelah dikeluarkannya undang-undang nomor 21 tahun 2008 tentang perbankan syariah. Menganalisa kinerja perbankan syariah jika dibandingkan dengan perbankan konvensional secara keseluruhan.

\section{KERANGKA TEORI DAN PENGEMBANGAN HIPOTESIS Teori Sinyal}

Teori sinyal menunjukkan adanya asimetri informasi antara manajemen perusahaan dan pihak-pihak yang berkepentingan dengan informasi tersebut. Berkaitan dengan asimetri informasi, sangat sulit bagi investor dan kreditor untuk membedakan antara perusahaan yang berkualitas tinggi dan rendah. Scott (1997) menyatakan bahwa terdapat dua tipe asimetri informasi yaitu: Adverse selection adalah para manajer serta orang dalam lainnya biasanya mengetahui lebih banyak informasi dibandingkan investor sebagai pihak luar. Moral hazard adalah kegiatan yang dilakukan oleh seorang manajer tidak seluruhnya diketahui oleh pengguna saham ataupun pemberi pinjaman.

Teori sinyal mengemukakan tentang bagaimana seharusnya sebuah perusahaan memberikan sinyal-sinyal kepada pengguna laporan keuangan. Sinyal ini berupa informasi mengenai apa yang sudah dilakukan oleh manajemen untuk merealisasikan keinginan pemilik. Sinyal dapat berupa promosi atau informasi lainnya yang menyatakan bahwa perusahaan tersebut lebih baik daripada perusahaan lainnya (Machfoedz, 1999). Menurut Diamond (1985) pengumuman informasi publik akan mengurangi dorongan bagi investor dalam memperolehi nformasi privat, karena informasi publik akan membuat kepercayaan investor lebih homogeneous dan mengurangi spekulasi investor yang memiliki informasi yang superior. Wolk et. al. (200o) menyatakan salah satu cara untuk mengurangi asimetri informasi keuangan dengan memberikan sinyal kepada pihak luar, salah satunya berupa informasi keuangan yang dapat dipercaya dan akan mengurangi ketidakpastian mengenai prospek perusahaan yang akan datang.

\section{Rasio Keuangan}

Rasio - rasio keuangan perusahaan merupakan salah satu bentuk informasi akuntansi yang penting dalam proses penilaian kinerja perusahaan, dengan rasio-rasio keuangan tersebut akan tampak jelas berbagai indikator keuangan yang dapat mengungkapkan kondisi keuangan suatu perusahaan maupun kinerja yang telah dicapai perusahaan untuk suatu periode tertentu. Rasio keuangan adalah angka yang diperoleh dari perbandingan dari satu pos laporan keuangan dengan pos lainnya yang mempunyai hubungan yang relevan. Analisis laporan keuangan khususnya memperhatikan pada penghitungan rasio keuangan agar dapat mengevaluasi keadaan pada masa lalu, sekarang dan proyeksi hasil di masa datang. 
Rasio keuangan adalah perbandingan antara dua elemen akun yang menunjukkan suatu indikator kesehatan keuangan pada waktu tertentu (BEJ, 2001). Rasio keuangan menyederhanakan informasi yang menggambarkan hubungan antara pos tertentu dengan pos lainnya. Dengan penyederhanaan ini dapat dinilai secara cepat hubungan antara pos tadi dan dapat membandingkannya dengan rasio lain sehingga diperoleh informasi dan diberikan penilaian. Rasio keuangan yang diolah dari laporan keuangan sangat penting dalam melakukan analisis terhadap kondisi keuangan oleh berbagai pihak (Itan dan Syakhroza, 2003).

Menurut Prastowo (2005) dalam Yaya (2008) untuk menilai kinerja keuangan suatu perusahaan diperlukan ukuran-ukuran. Salah satu cara untuk mempelajari dan mengukur keadaan keuangan perusahaan adalah dengan analisis rasio keuangan.

Derbel et. al., (2011) menyoroti manfaat keuangan Islam. Secara teoritis, beberapa penelitian telah menunjukkan bahwa jenis pembiayaan secara syariah dapat mengurangi efek dari krisis. Untuk menggambarkan secara empiris laporan ini, mereka menggunakan model ekonometrik yaitu model VAR untuk kasus pasar keuangan Amerika Serikat, Perancis, Saudi Saudi dan Indonesia.

Hasil penelitian menunjukkan bahwa penyebaran krisis lemah dalam pasar yang berdasarkan keuangan syariah. Mereka menemukan bahwa terjadi penurunan indeks di Amerika Serikat dan Perancis dibandingkan dengan di Arab Saudi dan di Indonesia. Jadi, efek negatif guncangan lebih terasa pada pasar konvensional. Tidak seperti keuangan konvensional yang secara berkala dilanda krisis dari berbagai tingkat keparahan, keuangan Islam dapat dianggap sebagai sistem keuangan yang stabil dan efisien untuk menyerap guncangan, dan mampu mendorong pertumbuhan dan penciptaan lapangan kerja.

Beberapa analis keuangan menganggap bahwa keuangan syariah, berdasarkan sifatnya, lebih stabil daripada keuangan konvensional (Moody`s (2008), Bouslama.G (2008), Drown.C (2009) dalam Derbel et al., (2011). Pelarangan bunga dan pembagian keuntungan dan kerugian menciptakan sistem keuangan berdasarkan aset riil. Sehingga bank tidak dapat melaksanakan proses spekulatif. Kredit yang diberikan berdasarkan simpanan riil ini dan hanya memberikan kredit jika diinvestasikan secara langsung dalam kegiatan produktif. Bank-bank yang bersaing hanya untuk investasi riil dan sumber daya mereka diinvestasikan kembali dalam kegiatan nyata. Sehingga pertumbuhan ekonomi tidak terkena dampak negatif dari inflasi.

Di sisi lain, analis keuangan lainnya menganggap bahwa bank syariah tidak stabil dan dapat menyebabkan banyak risiko dalam sistem keuangan yang berbeda dari bank konvensional, seperti risiko likuiditas, risiko operasional dan risiko hukum. Choong dan Liu (2006) dalam Derbel et al., (2011) berpendapat bahwa layanan perbankan Islam, setidaknya seperti yang dilakukan di Malaysia, menyimpang dari prinsip berbagi keuntungan dan kerugian, dan dalam prakteknya tidak terlalu berbeda dengan sistem tradisional. Hasil penelitian mereka menunjukkan bahwa pertumbuhan yang cepat di sektor perbankan Islam pada prinsipnya disebabkan oleh kebangkitan Islam di dunia bukan karena prinsip pembagian keuntungan dan kerugian. Sehingga menurut mereka perlu peraturan yang sama antara bank syariah dengan bank konvensional.

Pendapat ini didukung oleh Sadr dan Iqbal (2002) dalam Muda dan Ismail (2010) yang menyatakan walaupun prinsip bagi hasil menjadi ciri khas bank syariah, namun risiko yang dihadapi cukup besar yaitu risiko terjadinya moral hazard dan biaya transaksi tinggi, sebagaimana dikemukakan berikut:

Islamic banking in principles promotes equity-based contracts. However, it is often claimed by critics of the Islamic banking that in the presence of transaction costs and asymmetrical information, equity-based contracts are subjected to higher degree of adverse selection and moral hazard. 
Pelarangan bunga dapat mengakibatkan kekurangan sumber pendanaan. Sehingga, bank syariah menghadapi hambatan tertentu dalam pengelolaan likuiditas. Noyer (2009) dalam Derbel et al., (2011), menyatakan kelemahan standarisasi produk dan kurangnya harmonisasi norma-norma Islam, karena perbedaan antara interpretasi dari ahli syariah, dapat meningkatkan risiko operasional dan terciptanya ketidakpastian hukum, prinsip pembagian keuntungan dan kerugian menjadi jauh lebih kompleks ketika volume transaksi bank meningkat.

Cihak dan Hesse (2008) dalam Derbel et al., (2011), menyatakan bahwa ketika ukuran bank syariah semakin besar maka akan lebih sulit untuk menyesuaikan sistem monitor terhadap kredit. Mereka juga menyatakan bahwa pangsa pasar bank syariah tidak berdampak signifikan pada kekuatan keuangan dari bank lain.

Hanif et al., (2011) menganalisis dan membandingkan kinerja bank syariah dengan bank konvensional di Pakistan. Sampel yang digunakan adalah 22 bank konvensional dan 5 bank syariah. Untuk pemahaman mendalam, indikator kinerja utama dibagi menjadi faktor eksternal dan internal bank. Analisis faktor eksternal termasuk mempelajari perilaku pelanggan dan persepsi tentang perbankan baik perbankan syariah maupun konvensional. Analisis faktor internal mengukur perbedaan kinerja bank syariah dan konvensional dalam hal profitabilitas, risiko likuiditas, kredit dan solvabilitas. Sembilan rasio keuangan digunakan yang dikenal sebagai "Bank-o-meter". Temuan penelitian mereka menunjukkan dalam hal profitabilitas dan likuiditas bank konvensional kinerjanya lebih baik, sedangkan dalam manajemen risiko kredit dan pemeliharaan solvabilitas perbankan syariah mempunyai kinerja yang lebih baik dibanding bank konvensional.

Safiullah (2010) melakukan studi perbandingan kinerja bank konvensional dengan bank syariah di Bangladesh. Empat bank konvensional dan empat bank syariah dijadikan sampel. Periode waktu untuk penelitian ini adalah 5 tahun dari 2004 sampai 2008. Analisis rasio digunakan untuk mengukur perkembangan bisnis, profitabilitas, likuiditas dan solvabilitas, komitmen terhadap ekonomi dan masyarakat, efisiensi dan produktivitas, untuk kedua jenis bank. Hasil penelitian menunjukkan bahwa kinerja bank-bank konvensional lebih baik dalam hal komitmen terhadap perekonomian dan masyarakat, produktivitas dan efisiensi daripada bank syariah.

Bilal et al., (2011) menginvestigasi efisiensi bank-bank Islam dengan membandingkannya dengan bank-bank komersial kecil di Pakistan selama jangka waktu 3 tahun dari 2006-2008. Untuk mengetahui mengetahui perkiraan efisiensi dari bank individu peneliti menggunakan metode Non-Parametrik Analisis Data Envelopment (DEA) dan menyimpulkan bahwa bank-bank islam lebih efisien daripada bank-bank komersial kecil di Pakistan.

Penelitian Ika dan Abdullah (2011) membandingkan kinerja keuangan bank syariah dengan bank konvensional sebelum berlakunya Undang-Undang Perbankan Syariah Indonesia No 21/2008. Data berdasarkan laporan keuangan bank yang dipilih sebagai sampel dari tahun 2000 sampai 2007 . Ukuran kinerja keuangan dinyatakan dalam berbagai rasio keuangan yang dikategorikan ke dalam profitabilitas, likuiditas, risiko, solvabilitas dan efisiensi. Untuk menguji hipotesis, Mann-Whitney digunakan untuk membandingkan kinerja keuangan bank syariah dengan bank konvensional. Secara umum, penelitian ini tidak menemukan perbedaan besar dalam kinerja keuangan antara bank syariah dengan bank konvensional, kecuali dalam hal likuiditas. Penelitian mereka menunjukkan bahwa bank syariah lebih likuid daripada bank konvensional.

Jaffar dan Manarvi (2011) dalam Hanif et. al. (2011) menguji dan membandingkan kinerja bank konvensional dengan bank syariah yang beroperasi di dalam wilayah Pakistan selama tahun 2005 sampai 2009 dengan uji CAMEL. 5 bank syariah dan 5 bank konvensional dipilih menjadi sampel. Rasio berbeda digunakan untuk mengevaluasi setiap elemen CAMEL. Studi ini menemukan bahwa kinerja bank syariah lebih baik dalam hal 
perolehan kecukupan modal dan posisi likuiditas sedangkan bank konvensional lebih baik dalam hal manajemen mutu dan kemampuan menghasilkan earnings. Kualitas aset untuk bank konvensional dan bank syariah hampir sama. Berdasarkan analisis rasio UNCOL menunjukkan kinerja yang lebih baik untuk bank syariah.

Laghari et al., (2011) melakukan perbandingan kinerja antara bank syariah dengan bank konvensional melalui rasio dan persepsi konsumen. Konsumen pada kedua bank puas dengan kinerja bank, dalam hal ini konsumen bank syariah lebih puas. Hasil regresi memperlihatkan bahwa ATM dan jaringan cabang adalah faktor signifikan yang mempengaruhi kinerja bank syariah.

Awan (2009) dalam Laghari et al., (2011) melakukan penelitian untuk jangka waktu dua tahun dari 2006-2008, yang meliputi 12 bank ( 6 bank syariah 6 bank konvensional) dan menemukan bahwa bank-bank Islam memiliki pertumbuhan yang konsisten sejak awal. Disimpulkan bahwa bank syariah lebih baik dari bank konvensional dalam berbagai aspek termasuk aset, deposito, pembiayaan, investasi, efisiensi, kualitas pelayanan dan pengembalian pinjaman. Hasil penelitian menunjukkan bahwa bank syariah menjadi alternatif yang lebih baik untuk memenuhi kebutuhan pelanggan dan masyarakat bisnis prinsip syariah. Bank syariah merupakan organisasi penyedia jasa.

Dalam literatur ekonomi dan perbankan syariah, Bank Syariah lebih tepat dianalogkan sebagai institusi investasi yang memperoleh keuntungan dari hasil investasi yang dilakukan dengan berbagai model transaksi yang sesuai dengan syariah. Dalam hal ini, nasabah sebagai pemilik dana berhak atas proporsi tertentu dari keuntungan yang diperoleh Bank. Jika Bank syariah memperoleh keuntungan yang tinggi, maka nasabah penabung akan memperoleh keuntungan yang tinggi juga, demikian sebaliknya (Yaya dkk., 2008).

\section{Hipotesis}

Hanif et al., (2011) menyatakan dalam hal profitabilitas dan likuiditas bank konvensional kinerjanya lebih baik, sedangkan dalam hal manajemen risiko kredit dan pemeliharaan solvabilitas perbankan syariah lebih baik, sedangkan Ika dan Abdullah (2011) secara umum tidak menemukan perbedaan besar dalam kinerja keuangan antara bank syariah dengan bank konvensional, kecuali dalam hal likuiditas. Penelitian mereka menunjukkan bahwa bank syariah lebih likuid daripada bank konvensional. Penelitian Bilal et al., (2011) menyimpulkan bahwa bank-bank islam lebih efisien daripada bank-bank komersial kecil di Pakistan. Berdasarkan penelitian terdahulu hipotesis dalam penelitian ini adalah:

H1: Terdapat perbedaan signifikan kinerja keuangan dilihat dari rasio profitabilitas antara bank syariah dengan bank konvensional selama tahun 2009 - 2011.

H2: Terdapat perbedaan signifikan kinerja keuangan dilihat dari rasio likuiditas antara bank syariah dengan bank konvensional selama tahun 2009 - 2011.

H3: Terdapat perbedaan signifikan kinerja keuangan dilihat dari rasio risiko dan solvabilitas antara bank syariah dengan bank konvensional selama tahun 2009 - 2011 .

H4: Terdapat perbedaan signifikan kinerja keuangan dilihat dari rasio profitabilitas antara bank syariah dengan bank konvensional selama tahun $2009-2011$.

\section{METODOLOGI PENELITIAN}

Ruang lingkup penelitian ini mencakup perbandingan kinerja keuangan antara bank syariah dengan bank konvensional setelah dikeluarkannya Undang-Undang Nomor 21 tahun 2008 tentang perbankan syariah. Sampel yang digunakan dalam penelitian ini adalah purposive sampling yaitu yang memenuhi kriteria. Dalam penelitian ini Bank Syariah yang dikelompokkan Bank Indonesia sebagai BUSN Non Devisa digunakan sebagai sampel untuk 
bank syariah. Sampel untuk bank konvensional adalah bank konvensional yang memenuhi kriteria sebagai berikut:

a. Berdasarkan pengelompokan Bank Indonesia termasuk kelompok BUSN Non Devisa.

b. Tidak mempunyai unit usaha syariah selama $2009-2011$.

c. Tidak mengalami rugi selama tahun $2009-2011$

d. Laporan keuangan bank tersedia secara lengkap di website resmi bank.

\section{Metode Pengumpulan Data}

Metode yang digunakan untuk mengumpulkan data yang diperlukan dalam penelitian ini adalah: dokumentasi, dilakukan dengan cara mengumpulkan, menyalin, serta mengevaluasi laporan serta dokumen-dokumen yang terkait dengan obyek penelitian. Data penelitian berupa laporan keuangan bank yang dijadikan sampel yang diperoleh dari website resmi bank yang dijadikan sampel dan website resmi Bank Indonesia.

\section{Metode Analisis Data}

Analisis data menggunakan Uji Mann-Whitney. Uji Mann-Whitney merupakan suatu uji nonparametrik untuk menguji apakah dua buah sampel yang independen berasal dari populasi yang sama. Uji Mann-Whitney digunakan untuk membandingkan rata-rata dari dua sampel dari dua populasi. Untuk menentukan apakah perbedaan rata-rata signifikan, Asymp. Sig (2-tailed) harus lebih kecil dari 0.05. Jika Asymp. Sig (2-tailed) lebih kecil dari 0.05 , hipotesis alternatif (terdapat perbedaan antara groups mean) akan diterima, dapat dinyatakan sebagai berikut:

Jika nilai Asymp. Sig (2-tailed) > o,o5 maka Hi ditolak

Jika nilai Asymp. Sig (2-tailed) < o,05 maka Hı diterima.

\section{Operasionalisasi Variabel Penelitian}

Kinerja keuangan adalah gambaran tentang setiap hasil ekonomi yang mampu diraih oleh perusahaan perbankan pada saat periode tertentu melalui aktivitas-aktivitas perusahaan untuk menghasilkan keuntungan secara efesien dan efektif, yang dapat diukur perkembangannya dengan mengadakan analisis terhadap terhadap data-data keuangan yang tercermin dalam laporan keuangan. Untuk mengukur keberhasilan suatu perusahaan pada umumnya berfokus pada laporan keuangan disamping data-data non keuangan lain yang bersifat sabagai penunjang. Informasi kinerja bermanfaat untuk memprediksi kapasitas perusahaan dalam menghasilkan arus kas dari sumber dana yang ada (Ardiyana dan Muid). Kinerja keuangan bank diukur dengan menggunakan 13 rasio yang diadopsi Samad dan Hassan (2000); Samad (2004) dalam Ika dan Abdullah (2011). Rasio -rasio ini dikelompokkan ke dalam empat kategori yaitu: rasio profitabilitas, rasio likuiditas, rasio risiko dan solvency, dan rasio efisiensi.

\section{Rasio Profitabilitas.}

Rasio profitabilitas digunakan untuk menilai kemampuan perusahaan dalam menghasilkan earnings dibandingkan dengan beban-beban dan biaya relevan lainnya yang terjadi selama periode tertentu. Rasio - rasio yang digunakan umtuk mengukur profitabilitas bank adalah: Return on Asset (ROA), Return on Equity (ROE), Profit to Total Expenses (PER) dan Return on Deposit (ROD) (Ika dan Abdullah, 2011).

\section{a. Return on Asset (ROA)}

Rasio ini memperlihatkan bagaimana kemampuan bank menggunakan asetnya untuk mendapatkan pengembalian. Nilai yang lebih tinggi untuk rasio ini mengindikasikan kemampuan perusahaan yang lebih tinggi. Rasio ini merupakan indikator untuk 
mengevaluasi efisiensi manajerial (Samad, 1999; Samad and Hassan, 2000; Samad, 2004; Kader, et al., 2007) dalam Ika dan Abdullah (2011).

$$
R O A=\frac{\text { profit after tax }}{\text { total asset }}
$$

b. Return on Equity (ROE)

Rasio ini memperlihatkan bagaimana bank menghasilkan laba dengan modal yang diinvestasikan oleh pemegang saham. Nilai yang lebih tinggi untuk rasio ini memperlihatkan kinerja keuangan yang lebih tinggi pula. Rasio ini juga merupakan indikator untuk mengevaluasi efisiensi manajerial.

$$
R O E=\frac{\text { profit after tax }}{\text { equity capital }}
$$

c. Profit to Total Expenses (PER)

Rasio ini menunjukkan kemampuan perusahaan menghasilkan profit jika dibandingkan dengan total bebannya. Nilai yang tinggi menunjukkan bahwa bank dapat menghasilkan laba yang tinggi dengan beban tertentu.

$$
P E R=\frac{\text { profit after tax }}{\text { total expense }}
$$

\section{d. Return on Deposit (ROD)}

Rasio ini memperlihatkan persentase pengembalian dari setiap uang yang merupakan simpanan konsumen. Dengan kata lain, mengindikasikan keefektifan bank dalam mengkonversi simpanan terhadap laba bersihnya (Rosly and Bakar (2003).

$$
R O D=\frac{\text { profit after tax }}{\text { total deposit }}
$$

\section{Rasio Likuiditas}

Rasio ini mengukur kemampuan bank untuk memenuhi kewajiban jangka pendeknya. Semakin tinggi nilai pada rasio ini, menunjukkan bahwa perusahaan mempunyai margin safety yang lebih besar untuk memenuhi kewajiban jangka pendeknya. Rasio yang digunakan adalah: Cash Deposit Ratio (CDR), Loan Deposit Ratio (LDR), Current Ratio (CR) dan Current Asset Ratio (CAR).

a. Cash Deposit Ratio (CDR).

Semakin tinggi nilainya berarti perusahaan semakin likuid.

$$
C D R=\frac{\text { cash }}{\text { deposit }}
$$

b. Loan Deposit Ratio (LDR)

Nilai yang rendah dari rasio ini mengindikasikan bahwa bank memiliki kelebihan likuiditas. Rasio ini juga mengidentifikasikan keefektifan fungsi mediasi dari bank. Dalam konteks bank syariah, rasio ini dikenal sebagai Financing Deposit Ratio (FDR) 


$$
L D R=\frac{\text { loan }}{\text { deposit }}
$$

c. Current Ratio (CR)

Rasio ini menunjukkan kemampuan perusahaan untuk melunasi liabilitas lancar dengan aset lancarnya. Perusahaan yang mempunyai rasio yang tinggi berarti lebih likuid.

$$
C R=\frac{\text { current asset }}{\text { current liability }}
$$

d. Current Asset Ratio (CAR)

Rasio ini memperlihatkan komposisi aset perusahaan. Jika rasio ini tinggi nilainya, berarti perusahaan mempunyai lebih banyak aset lancar dibanding aset jangka panjangnya.

$$
C A R=\frac{\text { current asset }}{\text { total asset }}
$$

\section{Rasio Risiko dan Solvabilitas.}

Rasio-rasio yang digunakan untuk mengukur risk dan solvabilitas adalah: Debt equity ratio (DER), Debt to total assets ratio (DTAR), Equity multiplier ratio (EM) dan Loan to deposit ratio (LDR).

a. Debt equity ratio (DER)

Rasio ini memperlihatkan bagaimana pembiayaan operasi perusahaan dengan utang dibandingkan penggunaan ekuitas.

$$
D E R=\frac{\text { debt }}{\text { equity capital }}
$$

b. Debt to total assets ratio (DTAR)

Rasio ini mengindikasikan proporsi pembiayaan aset dengan utang. Nilai yang tinggi terhadap rasio ini menunjukkan bahwa perusahaan risiko bisnisnya lebih tinggi.

$$
D T A R=\frac{\text { debt }}{\text { total assets }}
$$

c. Equity multiplier ratio (EM)

Rasio ini menunjukkan berapa banyak rupiah aset harus didukung oleh setiap rupiah dari modal ekuitas. Nilai yang lebih tinggi dari rasio ini menunjukkan sinyal risiko kegagalan.

$$
E M=\frac{\text { total assets }}{\text { share capital }}
$$

d. Loan to deposit ratio (LDR)

Selain mengukur likuiditas, rasio ini juga mengindikasikan risiko kredit untuk perusahaan. Tingginya nilai rasio ini menunjukkan kemungkinankebangkrutan.

$$
L D R=\frac{\text { loan }}{\text { deposit }}
$$




\section{Rasio Efisiensi.}

Dua rasio yang digunakan untuk mengukur efisiensi suatu bank adalah: Asset Utilization ratio (AU) dan Operating Efficiency ratio (OE).

a. Asset Utilization ratio (AU).

Rasio ini mengukur kemampuan perusahaan perusahaan untuk menghasilkan pendapatan dengan aset yang dimilikinya. Nilai rasio yang tinggi menunjukkan bahwa perusahaan memiliki produktifitas yang tinggi terhadap aset perusahaan.

$$
A U=\frac{\text { total operating income }}{\text { total asset }}
$$

b. Operating Efficiency ratio (OE).

Rasio ini mengukur efisiensi perusahaan dalam menggunakan asetnya dengan meminimalkan beban dan meningkatkan produktifitas. Rasio ini diukur dengan membagi total operating expenses dengan total operating income

$$
O E=\frac{\text { total operating expenses }}{\text { total operating income }}
$$

\section{HASIL DAN PEMBAHASAN}

Gambaran umum bank yang dijadikan sampel bersumber dari dari website resmi bank dan laporan tahunan bank tahun 2011. Bank yang dijadikan sampel penelitian adalah BUSN Non Devisa. Perusahaan yang dijadikan sampel adalah 3 bank Syariah dan 8 bank konvensional. Bank Konvensional yang dijadikan sampel adalah:

1. PT Bank Harda Internasional

2. PT Bank Ina Perdana

3. PT Bank Jasa Jakarta

4. PT Bank Kesejahteraan

5. PT Bank Royal Indonesia

6. PT Bank Dipo Internasional

7. PT Bank Sinar Harapan Bali

8. PT Nationalnobu

Bank syariah yang dijadikan sampel adalah:

1. PT Bank Syariah Bukopin

2. PT BCA Syariah

3. PT Bank Victory Syariah

Kinerja keuangan dilihat dari rasio profitabilitas antara bank syariah dengan bank konvensional selama tahun 2009 - 2011 .

Hasil pengolahan data untuk kinerja keuangan yang diukur dengan rasio profitabilitas sebagai berikut: 
Tabel 1. Mann-Whitney Test

Test Statistics $(b)$

\begin{tabular}{|l|r|r|r|r|}
\hline & \multicolumn{1}{|c|}{ ROA } & \multicolumn{1}{c|}{ ROE } & \multicolumn{1}{c|}{ PER } & \multicolumn{1}{c|}{ ROD } \\
\hline Mann-Whitney U & 42.000 & 57.000 & 50.000 & 81.500 \\
Wilcoxon W & 70.000 & 85.000 & 78.000 & 109.500 \\
Z & -1.984 & -1.276 & -1.606 & -.118 \\
Asymp. Sig. (2- & .047 & .202 & .108 & .906 \\
tailed) & & & & \\
$\begin{array}{l}\text { Exact Sig. [2*(1- } \\
\text { tailed Sig.)] }\end{array}$ & $.048^{\mathrm{a}}$ & $.216^{\mathrm{a}}$ & $.115^{\mathrm{a}}(\mathrm{a})$ & $.908^{\mathrm{a}}$ \\
\hline
\end{tabular}

a Not corrected for ties.

b Grouping Variable: Jenis_Bank

Dari hasil test statistitics terlihat kinerja keuangan yang diukur dengan rasio profitabilitas ROA, ROE, PER dan ROD memperlihatkan Asymp. Sig. (2-tailed) masing masing 0.048; 0.216; 0.115 dan 0.908 sehingga hanya rasio Return on Asset (ROA) yang berbeda antara bank syariah dengan bank konvensional sedangkan kinerja keuangan yang diukur dengan ROE, PER dan ROD tidak terdapat perbedaaan.

Rasio ROA memperlihatkan bagaimana kemampuan perusahaan menggunakan asetnya untuk mendapatkan pengembalian. Nilai yang lebih tinggi untuk rasio ini mengindikasikan kemampuan perusahaan yang lebih tinggi. Rasio ini merupakan indikator untuk mengevaluasi efisiensi manajerial. Rasio ROA perbankan syariah secara rata - rata lebih rendah daripada ROA bank konvensional, berarti profitabilitas bank syariah lebih rendah dibanding bank konvensional, hal ini kemungkinan disebabkan karena bank syariah yang menjadi sampel merupakan bank yang baru berdiri (paling lama umurnya 3 tahun) sehingga pihak manajemennya belum mempunyai pengalaman yang banyak dalam mengatur usahanya. Hasil penelitian ini mendukung hasil penelitian Hanif et al. (2011) yang menunjukkan bank konvensional dalam hal profitabilitas kinerjanya lebih baik, juga mendukung temuan Jaffar dan Manarvi (2011) dalam Hanif et al. (2011) yang menyatakan bank konvensional lebih baik kinerjanya dibanding bank syariah dalam hal kemampuan menghasilkan earning.

\section{Kinerja keuangan dilihat dari rasio likuiditas antara bank syariah dengan bank konvensional selama tahun 2009 - 2011}

Hasil pengolahan data untuk kinerja keuangan yang diukur dengan rasio likuiditas sebagai berikut:

Tabel 2. Mann-Whitney Test

Test Statistics $(\mathbf{b})$

\begin{tabular}{|l|r|r|r|r|}
\hline & \multicolumn{1}{|c|}{ CDR } & \multicolumn{1}{c|}{ LDR } & \multicolumn{1}{c|}{ CR } & \multicolumn{1}{c|}{ CAR } \\
\hline Mann-Whitney & 77.500 & 77.000 & 60.000 & 60.000 \\
U & 377.500 & 105.000 & 88.000 & 88.000 \\
Wilcoxon W & -.307 & -.331 & -1.134 & -1.134 \\
Z & .759 & .741 & .257 & .257 \\
Asymp. Sig. (2- & $.764^{\mathrm{a}}$ & $.764^{\mathrm{a}}$ & $.274^{\mathrm{a}}$ & $.274^{\mathrm{a}}$ \\
tailed) & & & \\
Exact Sig. [2*(1- & & & \\
tailed Sig.)] & &
\end{tabular}

a Not corrected for ties.

b Grouping Variable: Jenis_Bank 
Dari hasil test statistitics terlihat kinerja keuangan yang diukur dengan rasio likuiditas CDR, LDR, CR dan CAR memperlihatkan Asymp. Sig. (2-tailed) masing - masing $0.764 ; 0.764 ; 0.274$ dan 0.274 sehingga tidak terdapat perbedaan kinerja keuangan antara bank syariah dan bank konvensional yang dilihat dari rasio likuiditas. Hasil penelitian ini tidak mendukung hasil penelitian Ika dan Abdullah (2011); Jaffar dan Manarvi (2011) yang menemukan bahwa bank syariah lebih likuid dibanding bank konvensional. Hasil ini juga tidak mendukung hasil penelitian Hanif et al. (2011) yang menyatakan kinerja bank konvensional lebih baik dibanding bank syariah dalam hal likuiditas.

\section{Kinerja keuangan dilihat dari rasio risiko dan solvabilitas antara bank syariah dengan bank konvensional selama tahun 2009 - 2011}

Hasil pengolahan data untuk kinerja keuangan yang diukur dengan rasio risiko dan solvabilitas sebagai berikut:

Tabel 3. Mann-Whitney Test

Test Statistics $(b)$

\begin{tabular}{|l|r|r|r|r|}
\hline & \multicolumn{1}{|c|}{ DER } & \multicolumn{1}{c|}{ DTAR } & \multicolumn{1}{c|}{ EM } & \multicolumn{1}{c|}{ LDR } \\
\hline Mann- & 49.000 & 81.000 & 41.000 & 77.000 \\
Whitney U & & & & \\
Wilcoxon & 77.000 & 381.000 & 69.000 & 105.000 \\
W & -1.654 & -.142 & -2.032 & -.331 \\
Z & .098 & .887 & .042 & .741 \\
Asymp. Sig. & & & & \\
(2-tailed) & $.104^{\mathrm{a}}$ & $.908^{\mathrm{a}}$ & $.043^{\mathrm{a}}$ & $.764^{\mathrm{a}}$ \\
$\begin{array}{l}\text { Exact Sig. } \\
\text { [2*(1-tailed }\end{array}$ & & & & \\
Sig.) & & &
\end{tabular}

a Not corrected for ties.

b Grouping Variable: Jenis_Bank

Dari hasil test statistitics terlihat kinerja keuangan yang diukur dengan rasio risiko dan solvabilitas DER, DTAR, EM dan LDR memperlihatkan Asymp. Sig. (2-tailed) masing masing 0.104; 0.908; 0.043 dan 0.764 sehingga hanya rasio Equiy Multiplier Ratio (EM) yang berbeda antara bank syariah dengan bank konvensional sedangkan kinerja keuangan yang diukur dengan DER, DTAR, dan LDR tidak berbeda antara bank syariah dengan bank konvensional.

Nilai yang lebih tinggi dari rasio Equity Multiplier (EM) menunjukkan sinyal risiko kegagalan. Perbankan syariah secara rata - rata lebih rendah rasio EMnya dibanding bank konvensional, dari hal ini dapat dianalisa bahwa risiko kegagalan bank syariah lebih rendah dibanding bank konvensional. Beberapa analis keuangan menganggap bahwa keuangan syariah, berdasarkan sifatnya, lebih stabil daripada keuangan konvensional (Moody's (2008), Bouslama.G (2008), Drown.C (2009) dalam Derbel et al., (2011). Pelarangan bunga dan pembagian keuntungan dan kerugian menciptakan sistem keuangan berdasarkan aset riil. Sehingga bank tidak dapat melaksanakan proses spekulatif. Kredit yang diberikan berdasarkan simpanan riil ini dan hanya memberikan kredit jika diinvestasikan secara langsung dalam kegiatan produktif. Bank-bank yang bersaing hanya untuk investasi riil dan sumber daya mereka diinvestasikan kembali dalam kegiatan nyata. Sehingga pertumbuhan ekonomi tidak terkena dampak negatif dari inflasi. Hasil penelitian ini mendukung temuan Hanif et al (2011) yang menyatakan dalam hal manajemen risiko kredit dan pemeliharaan solvabilitas bank syariah kinerjanya lebih baik. 


\section{Kinerja keuangan dilihat dari rasio efisiensi antara bank syariah dengan bank konvensional selama tahun 2009 - 2011}

Tabel 4. Mann-Whitney Test Test Statistics $(b)$

\begin{tabular}{|l|r|r|}
\hline & \multicolumn{1}{|c|}{ AU } & \multicolumn{1}{|c|}{ OE } \\
\hline Mann-Whitney U & 58.000 & 53.000 \\
Wilcoxon W & 86.000 & 353.000 \\
Z & -1.229 & -1.465 \\
Asymp. Sig. (2-tailed) & .219 & .143 \\
Exact Sig. [2*(1-tailed Sig.)] & $.234^{\mathrm{a}}$ & $.153^{\mathrm{a}}$ \\
\hline
\end{tabular}

a Not corrected for ties.

b Grouping Variable: Jenis_Bank

Dari hasil test statistitics terlihat kinerja keuangan yang diukur dengan rasio efisiensi AU dan OE memperlihatkan Asymp. Sig. (2-tailed) masing - masing 0.234; dan o.153 sehingga tidak terdapat perbedaan kinerja keuangan antara bank syariah dan bank konvensional yang dilihat dari rasio efisiensi. Hasil penelitian ini tidak mendukung Safiulah (2010) yang menyatakan bank konvensional lebih efisien, juga tidak mendukung hasil penelitian Bilal et al. (2011) yang menyatakan bank Islam lebih efisien daripada bank - bank komersial kecil di Pakistan.

\section{SIMPULAN}

Penelitian ini bertujuan untuk menganalisis perbedaan kinerja keuangan Bank Syariah dibandingkan dengan Bank Konvensional setelah dikeluarkan Undang - Undang Nomor 21 Tahun 2008 Tentang Perbankan Syariah, dari hasil pengolahan data dapat disimpulkan: Kinerja keuangan yang dilihat dari rasio profitabilitas antara bank syariah dengan bank konvensional selama tahun 2009 - 2011, hanya berbeda pada rasio ROA saja, sedangkan ROE, PER dan ROD tidak berbeda. Kinerja keuangan yang dilihat dari rasio likuiditas antara bank syariah dengan bank konvensional selama tahun 2009 - 2011 tidak berbeda. Kinerja keuangan yang dilihat dari rasio risiko dan solvabilitas antara bank syariah dengan bank konvensional selama tahun 2009 - 2011, hanya berbeda pada rasio Equity Multiplier (EM) saja, sedangkan rasio DER, DTAR dan LDR tidak berbeda. Kinerja keuangan yang dilihat dari rasio efisiensi antara bank syariah dengan bank konvensional selama tahun 2009 - 2011 tidak berbeda. Secara keseluruhan dari 14 rasio yang digunakan untuk membandingkan kinerja keuangan antara bank syariah dengan bank konvensional hanya 2 rasio yang berbeda.

\section{PUSTAKA ACUAN}

Antonio, Muhammad Syafii.20o1. Bank Syariah: Dari Teori ke Praktek. Gema Insani bekerjasama dengan Yayasan Tazkia Cendikia.

Ardiyana, Marisa dan Dul Muid. Analisis Perbandingan Kinerja Keuangan Bank Syari'ah dan Bank Konvensional Sebelum, Selama, dan Sesudah Krisis Global Tahun 20o8. Dengan Menggunakan Metode CAMEL diakses dari http://eprints.undip.ac.id/ 29852 /1/ JURNAL.pdf tanggal 1 September 2012.

Bank Indonesia. .2011. Institusi Perbankan di Indonesia. Diakses dari http://www .bi.go.id/ web/id/Perbankan/Ikhtisar+Perbankan/Lembaga+Perbankan/ 
BEJ. 2001. Perangkat dan Teknik Analisis Investasi Di Pasar Modal Indonesia, Jakarta. Penerbit PT Bursa Efek Jakarta

Bilal, H., Ahmad, K., Ahmad, H., \& Akbar, S. 2011. Returns To Scale Of Islamic Banks Versus Small Commercial Banks In Pakistan. European Journal Of Economics, Finance And Administrative Sciences (30).

Derbel, H., Bouraoui, T. and Dammak, N. 2011. Can Islamic Finance Constitute A Solution to Crisis? International Journal of Economics and Finance Vol. 3, No. 3; August

Djumena,Erlangga. 2012. Diakses dari http://bisniskeuangan.kompas.com/read/2012/03/21/13593993/BI.5.Tahun.Pangsa.Pas ar.Syariah.Bisa.10.Persen tanggal 2 April 2012

Hamdan, Umar, dan Andi Wijaya. 2006. "Analisis Komparatif Resiko Keuangan Bank Perkreditan Rakyat (BPR) Konvensional Dan BPR Syariah”. Jurnal Manajemen \& Bisnis Sriwijaya Vol. 4, No 7 Juni 2006.

Hanif, M., Tariq Mahvish, Tahir Ashiya and Momeneen. 2011. Comparative Performance Study of Conventional and Islamic Banking in Pakistan Electronic copy available at: http://ssrn.com/abstract $=1959950$

Haniffa, R. \& Hudaib, M. 2007. Exploring the Ethical Identity of Islamic Banks via Commnication in Annual Reports. Journal of Business Ethics, 76.

Ika, Siti Rochmah and Abdullah, Norhayati. 2011. A Comparative Study of Financial Performance of Islamic Banks and Conventional Banks in Indonesia. International Journal of Business and Social Science. Vol. 2 No. 15; August

Itan, Iskandar dan Syakhroza, Akhmad. 2003. The Influence of Financial Performance to The Price of LQ45 Stocks At Jakarta Stock Exchange. SNA VI, Surabaya

Kader, J.M., Asarpota, A.J. and Al-Maghaireh, A. 2007. Comparative Financial Performance of Islamic Banks vis-à-vis Conventional Banks in the UAE. Proceeding on Annual Student Research Symposium and the Chancellor's Undergraduate Research Award. (Online) Available: http://sra.uaeu.ac.ae/CURA/Proceedings

Laghari, Minhoon Khan, Iram Rani, Niaz Ahmed Bhutto and Falah-ud-Din Butt. 2011. Comparative Analysis of Islamic Bank With Conventional Banks. Interdisciplinary Journal of Contemporary Research in Business. November Vol 3, No 7.

Machfoedz, Mas'ud. 1999. Pengaruh Krisis Moneter pada Efisiensi Perusahaan Publik di Bursa Efek Jakarta. Jurnal Ekonomi dan Bisnis Indonesia, Vol. 14 No.1

Muda, Ruhaini and Abdul Ghafar Ismail. 2010. Profit-Loss Sharing and Value Creation in Islamic Banks. Journal of Business and Policy Research Volume 5. Number 2. December 2010

Prasetyo, Indra. 2008. Analisis Kinerja Keuangan bank Syariah dan Bank Konvensional. Jurnal Aplikasi Manajemen. Vol 6, No 2, Hal 164-168.

Rosly, S.A and Bakar, M.A.A. 2003. Performance of Islamic and Mainstream Banks in Malaysia. International Journal of Social Economics, 30 (12), 1249-1265.

Safiullah, M. 2010. Superiority of Conventional Banks E Islamic Banks of Bangladesh:A Comparative Study. International Journal of Economics and Finance 2: 3.

Suyanto, M. "Perbandingan Kinerja Bank Islam Terhadap Bank Persero, Bank Asing Dan Bank Umum Di Indonesia Pada 2000 - 2004".

Undang - Undang Republik Indonesia Nomor 21 Tahun 2008 tentang Perbankan Syariah.

Undang - Undang Republik Indonesia Nomor 7 Tahun 1992 tentang Perbankan Sebagaimana Telah Diubah Dengan Undang - Undang Nomor 1o Tahun 1998

Wisdagdo, Ari Kuncara, dan Siti Rochmah Ika. 2008. "The Interset Prohabition and Financial Performance of Islamic Banks: Indonesia Evidence”.International Businees Research. Vol 1, No. 3.

Wulandari, Novita. 2004. Keunggulan Komparatif Bank Syariah, Suara Merdeka, Senin 22 Nopember 2004. 
Yaya, Rizal, Ahim Abdurrahim dan Peni Nugraheni. 2008. Kesenjangan Harapan Antara Nasabah dan Manajemen Terhadap Penyampaian Informasi Keuangan dan Non Keuangan Bank Syariah: Studi Empiris Bank Syariah di Yogyakarta dan Surakarta. SNA XI Pontianak

Zuhdi, Ramzi A. 2007. Usaha Syariah lebih Islami dan Governance. Akuntan Indonesia. Edisi No. 2 Tahun 1, Oktober. 